\title{
Kondisi Karang di Pulau Baranglompo dan Bone Batang Berdasarkan Tabel Kesehatan Karang
}

\author{
Muh. Nurdin, Magdalena Litaay, Dody Priosambodo, Willem Moka \\ Departemen Biologi, Fakultas Matematika dan Ilmu Pengetahuan Alam \\ Universitas Hasanuddin \\ email: nurdingingsul@gmail.com
}

\begin{abstract}
The structure of wing scales in four species of papilionid butterflies were The research about the condition of coral reefs in Baranglompo and Bone Batang island was conducted in January to April 2016 based on "Coralwatch" table. The aim of this study was to determine health condition of coral reefs in Baranglompo and Bone Batang island. The data was obtained in the south, west, and north at a depth of 3 meters and 10 meter using Line Intercept Transect (LIT) method along 100 meters of both islands. The health condition of coral reefs was obtained from four coral colony types specifically Branching, Massive, Tabulate, and Soft coral using Coralwatch method. The results of this study showed that the health condition of coral reefs in Baranglompo and Bone Batang islands was still relatively equal. At a depth of 3 meters, the most healthy coral colony was dominated by branching corals while at a depth of 10 meters dominated by massive corals. However, the average value of coral colors indicating coral condition showed that the health condition of coral reefs in Baranglompo was higher than that in Bone Batang island. High anthropogenic impacts were observed by the trash commonly found in Baranglompo island, many fish bombings also found in Bone Batang island. This study recommend that the health condition of coral reefs in Baranglompo island was greater than that in Bone Batang island.
\end{abstract}

Kata kunci: Coral health, Baranglompo island, Bone Batang island, Coralwatc

\section{PENDAHULUAN}

Berdasarkan hasil penelitian pada tahun 1998, luas terumbu karang Indonesia adalah 42.000 $\mathrm{km}^{2}$ atau 16,5\% dari luasan terumbu karang dunia yaitu seluas $255.300 \mathrm{~km}^{2}$ dengan 70 genera dan 450 spesies. Terumbu karang dan segala kehidupan yang terdapat di dalamnya merupakan salah satu kekayaan alam yang bernilai tinggi. Manfaat yang terkandung di dalam ekosistem terumbu karang sangat besar dan beragam, baik manfaat langsung dan manfaat tidak langsung (Sudiono, 2008).

Terumbu karang mempunyai berbagai fungsi yaitu, sebagai gudang keanekaragaman hayati biota-biota laut, tempat tinggal sementara atau tetap, tempat mencari makan, berpijah, daerah asuhan dan tempat berlindung bagi hewan laut lainnya. Terumbu karang juga berfungsi sebagai tempat berlangsungnya siklus biologi, kimiawi dan fisik secara global yang mempunyai tingkat produktivitas yang sangat tinggi. Terumbu karang merupakan sumber bahan makanan langsung maupun tidak langsung dan sumber obat-obatan. Terumbu karang sebagai pelindung pantai dari hempasan ombak dan sumber utama bahan-bahan kontruksi (Suharsono, 2008). 
Kerusakan terumbu karang Indonesia terus meningkat setiap tahun. Penelitian yang dilakukan Lembaga Ilmu Pengetahuan Indonesia (LIPI) pada 2011 menunjukkan 30.76 persen terumbu karang memiliki kondisi yang kurang baik atau rusak. Data yang dihimpun 1.076 stasiun pengamatan itu mengungkap hanya 5.58 persen karang yang kondisinya sangat baik; 26.95 persen baik dan 36.90 persen sisanya cukup baik (Coremap-CTI, 2012).

CoralWatch merupakan program internasional University of Queensland yang memantau kesehatan karang dan menyelenggarakan program pendidikan karang. CoralWatch menyediakan metoda sederhana untuk mengukur kesehatan karang, serta menganjurkan masyarakat untuk hidup dan bertindak dengan cara yang melindungi, tidak merusak, dan memperbaiki kondisi karang serta ekosistem lainnya (Dean dan Kleine, 2012).

Pulau Baranglompo dan Bone Batang merupakan pulau yang berada dalam zona yang sama di perairan Spermonde Makassar dan memiliki keanekaragaman terumbu karang. Terumbu karang memiliki peranan sangat penting bagi kehidupan ekosistem bawah laut dan masyarakat pulau. Belum adanya kajian khusus mengenai kondisi kesehatan karang di perairan Pulau Barang Lompo dan Bone Batang yang menjadi alasan penelitian ini. Melihat hal tersebut, maka perlunya dilakukan penelitian ini untuk mengetahui kondisi kesehatan karang di Pulau Baranglompo dan Bone Batang dengan menggunakan tabel kesehatan karang CoralWatch. Tabel kesehatan karang CoralWatch ini merupakan metode yang digunakan untuk mengukur kesehatan terumbu karang berdasarkan warna-warna terumbu karang yang umum dijumpai.

\section{METODE PENELITIAN}

Dalam melaksanakan pengambilan data terumbu karang terlebih dahulu mencatat data pendukung seperti menuliskan nama peneliti, nama spot penelitian, tanggal dan jam, posisi titik koordinat (GPS), suhu laut, kedalaman, aktifitas yang dilakukan untuk mengambil data seperti menyelam dan snorkeling serta kondisi cuaca, yang tersedia pada lembar data yang akan digunakan.

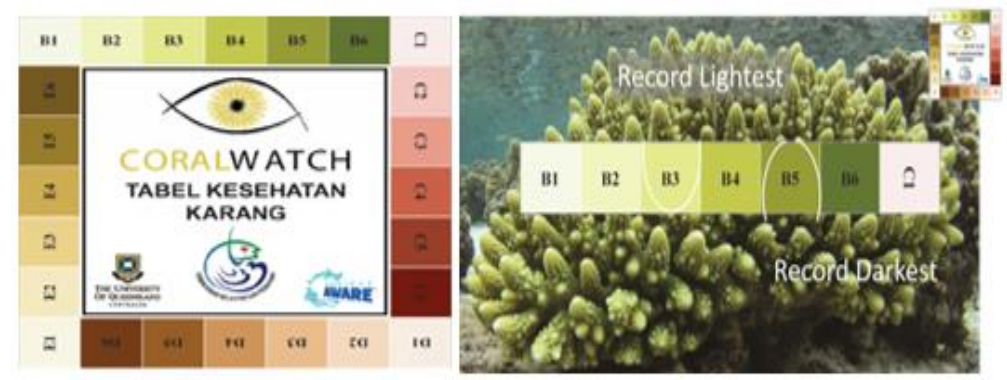

Gambar 1. Tabel kesehatan karang dan cara penggunaannya (Dean dan Kleine, 2012)

Pengambilan data penelitian dilakukan pada kedalaman 3 dan 10 meter di pulau Baranglompo dan Bone Batang menggunaka Line Transect sepanjang 100 meter dengan memilih sebuah koloni karang yang masuk dalam Transect dan mencatat warna karang yang paling tua serta warna paling muda untuk setap koloni, dengan ketentuan nilai warna yang tersedia dalam tabel kesehatan karang Coralwatch dan mencatat tipe karang dari setiap koloni karang. Data yang diambil yaitu, dengan mengamati 1-20 koloni karang yang berbeda dalam batas Transect atau satu stasiun. 


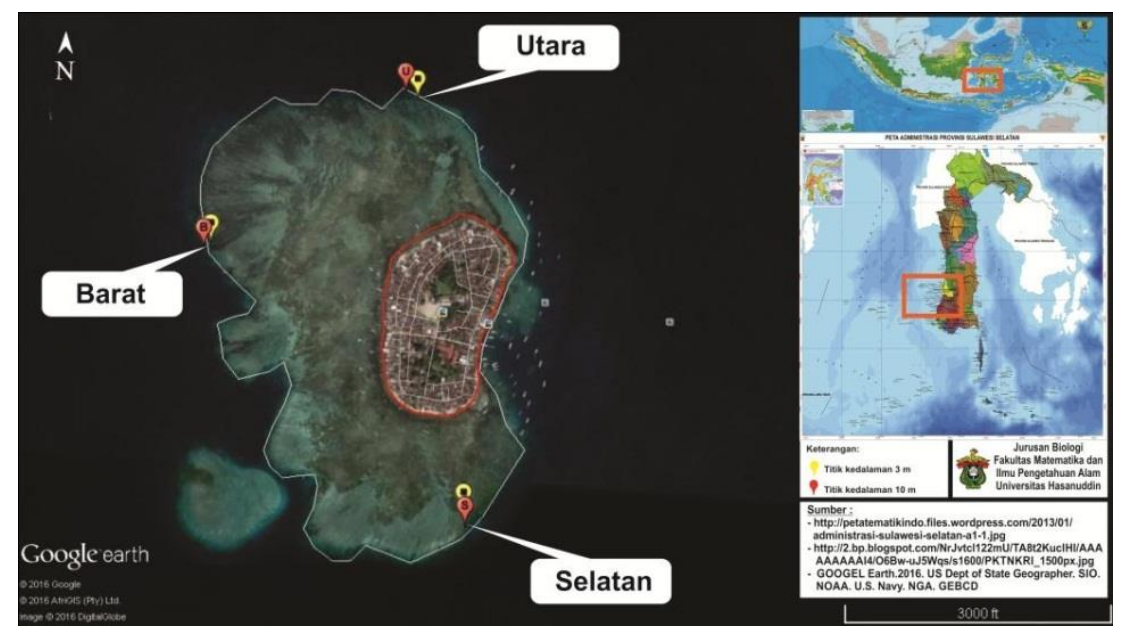

Gambar 2. Lokasi penelitian di pulau Baranglompo

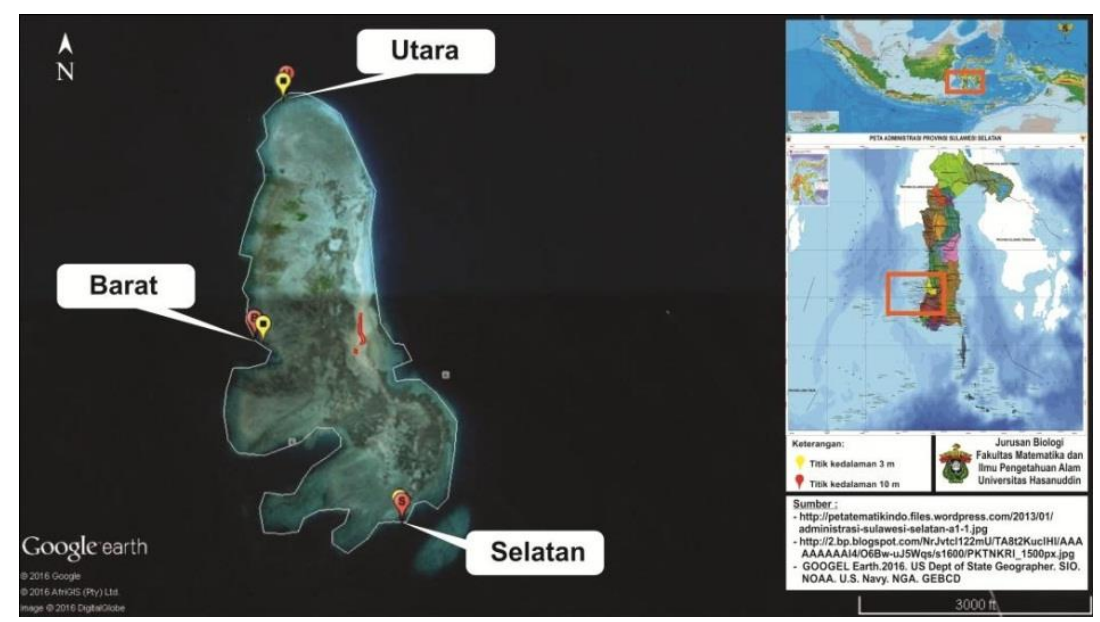

Gambar 3. Lokasi penelitian di pulau Bone Batang

\section{Pengambilan Data Dampak Antropogenik}

Pengambilan data dampak antropogenik atau aktifitas manusia menggunakan metode dalam Reef Check. (Hodgson et al, 2006).

\section{Pengolahan Data}

Pengolahan data dilakukan dengan memasukkan kurang lebih 1-20 koloni karang yang telah ditemukan kedalam entry excel coralwatch yang sudah tersedia dengan kolom-kolom pengolahan data yang sudah baku. Data yang dimasukkan kedalam entry excel Coralwatch akan diolah secara otomatis dan hasilnya berupa histogram persentase distribusi kesehatan karang serta nilai warna dan persentase bentuk koloni karang yang diamati. Penentuan kesehatan dengan menggunakan data dari pulau Heron yang diambil pada tahun 2002 untuk melihat standar sehat dan standar tidak sehat atau mengalami bleaching pada koloni karang. Begitu juga dengan data dari dampak antropogenik yang ditemukan akan dimasukkan kedalam lembar data entry excel Reef Chek yang sudah baku dan membentuk data histogram. 


\section{HASIL DAN PEMBAHASAN}

Pulau Baranglompo dan Bone Batang berada di kawasan kepulauan Spermonde, yang secara administrative pulau ini berada di kelurahan Baranglompo, kota Makassar, Provinsi Sulawesi Selatan. Baranglompo yang terletak $11.9 \mathrm{~km}$ dari kota Makassar dan secara geografis pulau Baranglompo terletak pada titik kordinat S 5 02' 48.50"; E 119 19' 48.12" dengan Jarak pulau Baranglompo dari kota Makassar \pm 7.37 mil dan Bone Batang yang terletak $15.0 \mathrm{~km}$ dari kota Makassar serta secara geografis pulau Bone Batang ini berada pada titik kordinat S 500'52.33"; E 119 $19^{\circ}$ 34.62" dengan jarak dari kota Makassar \pm 9.32 mil.

\section{Persentase koloni karang yang disurvei}

Hasil pengamatan terhadap koloni karang bercabang, masif, meja dan lunak pada masingmasing stasiun di pulau Baranglompo dan Bone Batang diperoleh persentase koloni karang yang bervariasi (Gambar 4). Untuk kedalaman $3 \mathrm{~m}$, di pulau Baranglompo persentase koloni karang tertinggi ditemukan pada koloni karang bercabang terutama di stasiun selatan dan barat. Sedangkan pada stasiun utara didominasi koloni karang masif. Kondisi serupa juga ditemukan pada seluruh stasiun di pulau Bone Batang yang didominasi oleh koloni karang bercabang. Hal ini sesuai dengan hasil penelitian Suryanti et al, (2011) bahwa pada kedalaman $3 \mathrm{~m}$ bagian selatan dan barat pulau Cemara Kecil, jenis karang yang mendominasi yaitu Acropora yang termasuk koloni karang bercabang.

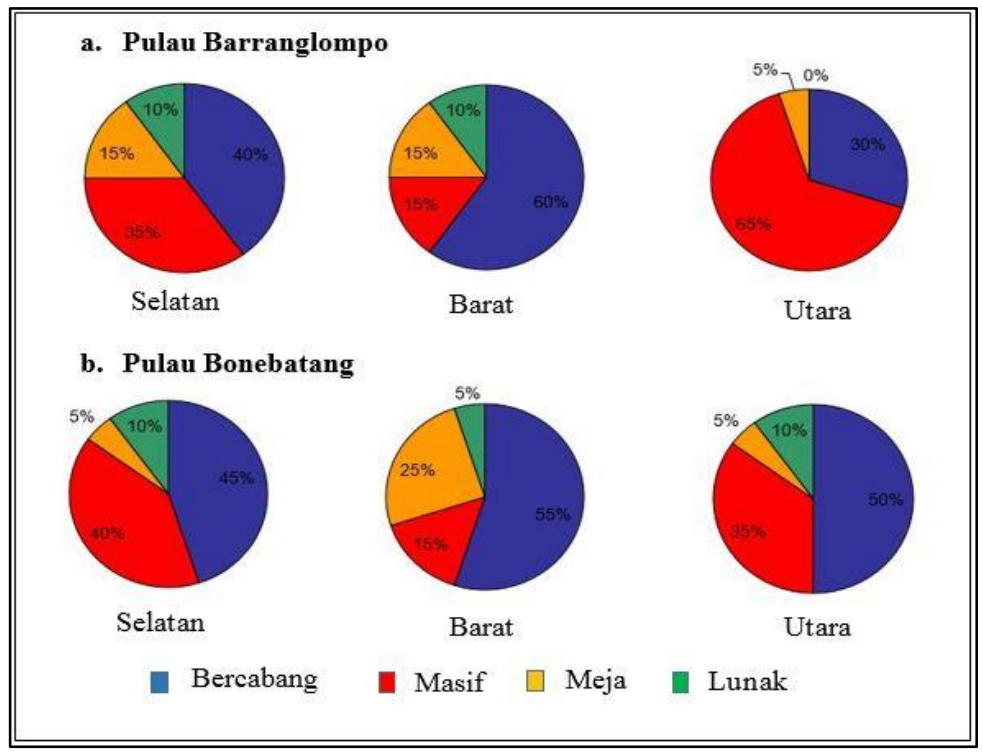

Gambar 4. Persentase koloni karang di pulau Baranglompo dan Bone Batang kedalaman $3 \mathrm{~m}$

Menurut English at al. (1994), bentuk pertumbuhan koloni karang dipengaruhi oleh empat faktor yaitu cahaya, tekanan hidrodinamis (gelombang dan arus), sedimen dan subareal exposure. Koloni karang bercabang di kedua pulau pada umumnya ditemukan di stasiun barat yang memiliki rataan terumbu yang luas dengan topografi yang lebih landai. Arus didaerah seperti ini umumnya tidak terlalu kuat sehingga sangat mendukung kehidupan untuk koloni karang bercabang dan koloni karang meja. Selanjutnya, untuk stasiun selatan dan utara persentase koloni karang masif lebih tinggi. Hal ini disebabkan karena stasiun ini memiliki topografi rataan terumbu yang lebih curam. Arus pada habitat 
seperti ini umumnya lebih kuat sehingga lebih cocok bagi pertumbuhan koloni karang masif. Sedangkan untuk koloni karang lunak yang persentase jenis yang paling rendah di seluruh stasiun pengamatan. Menurut Manuputty (1986), pada beberapa tempat terjadinya kelimpahan jenis karang lunak terutama pada daerah-daerah yang karang batunya baru mati akibat serangan bintang laut bulu seribu (Acanthaster palanci), jadi pada kondisi normal koloni karang lunak tidak banyak ditemukan pada ekosistem terumbu karang yang sehat.

Pada kedalaman $10 \mathrm{~m}$ (Gambar 5) persentase koloni karang pada masing-masing stasiun di kedua pulau didominasi oleh karang masif dan meja. Rataan terumbu pada kedalaman $10 \mathrm{~m}$, di seluruh staiun penelitian memiliki topograpi yang lebih curam dengan arus yang lebih kencang. Sedimen berpasir juga lebih banyak di temukan. Menurut Rahmitha et al, (2015) substrat berpasir terbentuk dari gerakan ombak yang terus menerus datang melalui pasang surut yang terjadi tiap harinya serta sejenis ikan karang yang memakan polip pada karang sehingga menyebabkan terbentuknya butiran-butiran kalsium karbonat. Menurut English et al, (1994) pada gelombang yang kuat (windward zones) kecenderungan pertumbuhan koloni karang yang ditemukan yaitu pada percabangan pendek, kuat, merayap atau submasif.

Koloni karang masif di kedua pulau pada umumnya ditemukan di stasiun selatan dan utara yang memiliki rataan terumbu yang sempit dengan topografi yang lebih curam. Arus didaerah seperti ini umumnya berarus kuat dan kencang sehingga yang dapat bertahan hidup ialah koloni karang masif. Sebagai mana hasil penelitian Suryanti et al, (2011) pada kedalaman 10 m didominasi oleh jenis koloni karang masif dan lebar seperti halnya stasiun barat persentase karang didominasi oleh jenis karang meja. Hal ini disebabkan karena stasiun ini memiliki topografi rataan terumbu yang lebih lebar. Arus pada habitat seperti ini umumnya lebih sedang sehingga lebih baik bagi pertumbuhan koloni karang meja dan untuk koloni karang bercabang sifatnya ditemukan merata pada setiap stasiun. Seperti halnya dikedalaman $3 \mathrm{~m}$, untuk koloni karang lunak yang persentase jenisnya paling rendah di seluruh stasiun pengamatan.

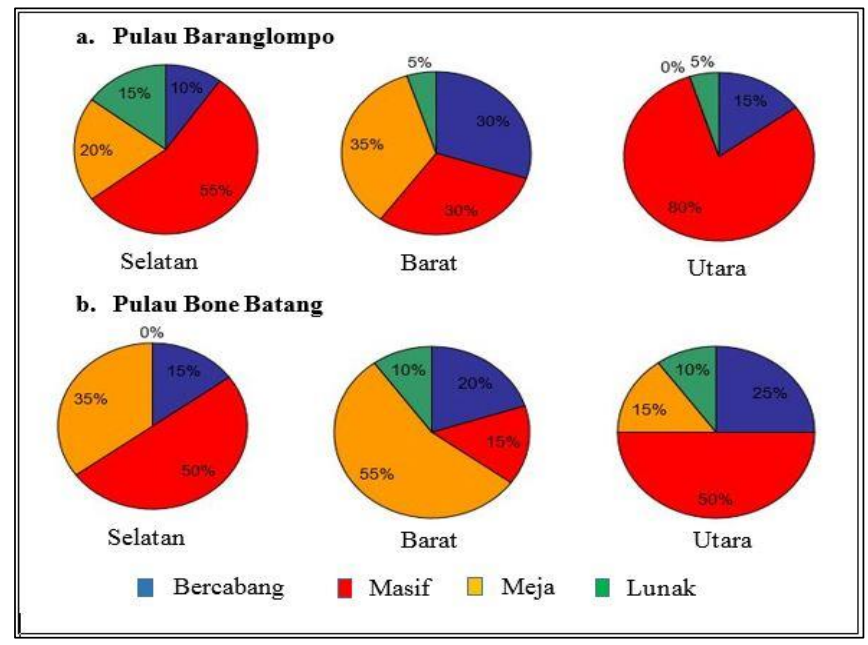

Gambar 5. Persentase koloni karang di pulau Baranglompo dan Bone Batang kedalaman $10 \mathrm{~m}$

Menurut Suryanti et al, (2011), Dari hasil pengamatannya bahwa kedalaman tidak berpengaruh terhadap morfologi karang, hal ini karena pada kedalaman yang berbeda jenis karang berdasarkan morfologi yang ditemukan relative tidak terdapat perbedaan nyata, hanya jumlah yang 
mendominasinya saja yang berbeda. Kehadiran jenis karang di suatu lokasi tergantung pada kondisi perairan setempat seperti cahaya matahari, salinitas, temperatur, pergerakan arus, substrat dan kecerahan air (Souhoka, 2009).

\section{Dampak Antropogenik}

Dampak antropogenik merupakan kerusakan yang diakibatkan oleh perbuatan manusia. Dari hasil pengamatan yang dilakukan untuk daerah pulau Barang Lompo dan Bone Batang, ada lima jenis dampak aktifitas manusia yang menjadi objek pengamat yaitu, boat/anchor, dynamite, other coral damage, fish nets dan trash. Boat/anchor atau jangkar kapal yang ditandai dengan kerusakan karang yang bentuknya memanjang. Kemudian dynamite atau bekas bom ditandai dengan kerusakan yang berbentuk seperti kawah dan terdapat pencahan karang (rubble). Selanjutnya other coral damage yaitu kerusakan yang terjadi diluar daripada ciri-ciri yang ditimbulkan oleh dampak boat/anchor dan dynamite, biasanya kerusakan ini terjadi akibat kegiatan manusia selain dari bom dan jangkar kapal, misalnya bius serta kegiatan parawisata yang menginjak atau mematahkan karang. Adapun fish nets dan trash ditandai dengan adanya jaring dan sampah pada daerah terumbu karang.

Hasil pengamatan dampak antropogenik di pulau Baranglompo dan Bone Batang diperoleh data yang bervariasi.(Gambar 6 dan 7). Untuk Barranglompo, dampak tergolong tinggi ditemukan banyaknya sampah terutama di stasiun selatan. Dimana sampah anorganik sangat mempengaruhi kondisi kesehatan karang dimana dari hasil penelitian Fujioka et al,, (2015) bahwa sampah anorganik yang sangat mempengaruhi ialah sampah kain, plastik hitam, plastik merah dan plastik putih. Berdasarkan hasil pengamatannya terlihat bahwa karang Acropora branching dan Tabulate memiliki kerentangan terjadinya pemutihan karang (bleaching) sedangkan untuk karang Massive dan Foliose memiliki daya tahan yang kuat terhadap pengaruh perlakuan sampah anorganik yang diujikan.

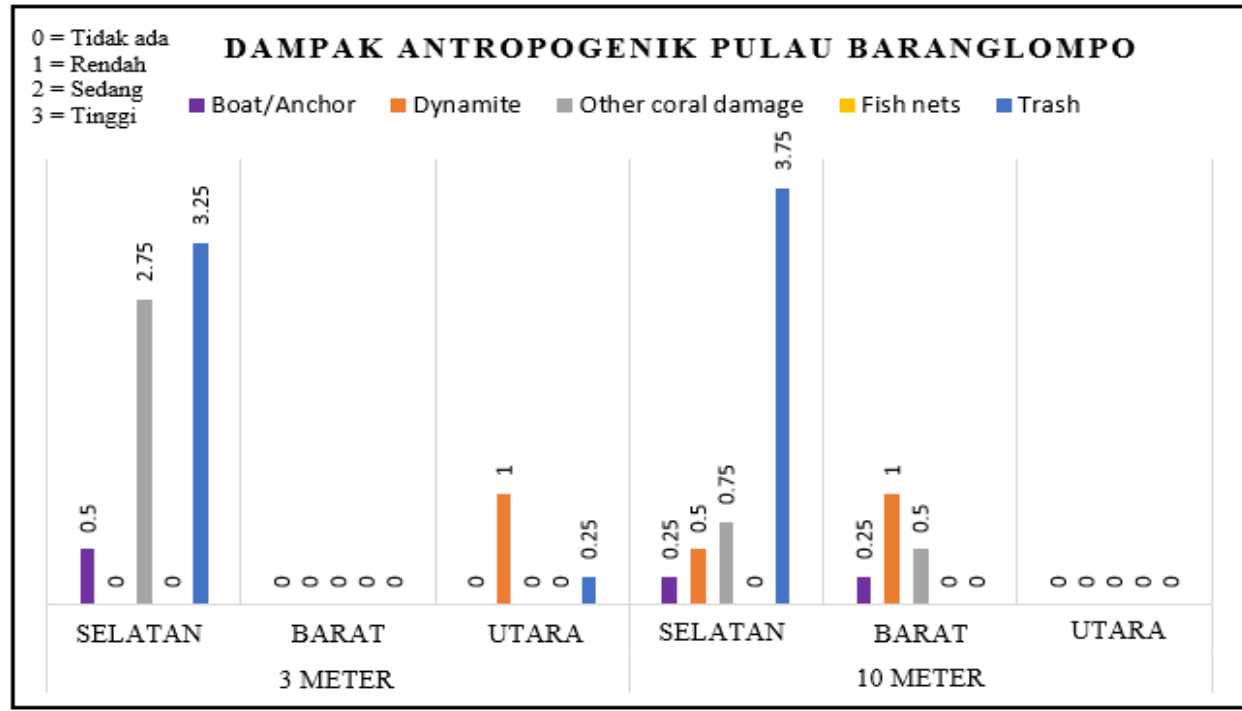

Gambar 6. Dampak antropogenik di pulau Baranglompo.

Untuk dampak lainnya masih tergolong sedang dan rendah. Secara keseluruhan dampak yang ditimbulkan oleh kegiatan manusia sangat memberikan dampak terhadap kelangsungan hidup terumbu karang sebagai mana yang ditegaskan Bryant et al, (1998) dalam Westmacott et al, (2000) analisa ancaman-ancaman yang potensial bagi terumbu karang dari kegiatan manusia yaitu (pembangunan 
daerah pesisir, eksploitasi berlebihan dan praktek perikanan yang merusak, polusi darat dan erosi serta polusi laut) di tahun 1998 memperkirakan bahwa 27\% dari terumbu berada di tingkat berisiko tinggi dan $31 \%$ lainnya berada diresiko sedang. Sedangkan pada pengamatan dampak antropogenik di pulau Bone Batang menunjukkan data bervariasi diseluruh stasiun seperti pada (Gambar 7).

Dimana dampak penggunaan bom merupakan dampak yang paling banyak ditemukan dan secara umum disemua stasiun tergolong tinggi. Juga ditemukan dampak dari kegiatan lainnya pada stasiun selatan tergolong tinggi. Hal ini disebabkan karena banyaknya kegiatan penangkapan ikan oleh nelayan yang tidak ramah lingkungan diseluruh bagian pulau. Halini sesuai menurut Dahuri et al, (1996), dampak dari aktivitas manusia terhadap kerusakan ekosistem terumbu karang seperti penambangan karang dengan atau tampa bahan peledak yang dapat menyebabkan perusakan habitat, bila menggunakan bahan peledak dapat menimbulkan kematian massal ekosistem terumbu karang. Kepariwisataan yang menyebabkan pencemaran limbah manusia, karena limbah tidak diolah secara memadai sebelum dibuang ke perairan lokasi terumbu karang yang berakibat terjadinya eutrofikasi dan menyebabkan perairan menjadi subur sehingga perairan menjadi keruh, kerusakan fisik terumbu karang akibat buangan jangkar kapal, pengambilan karang oleh pengunjung dan rusaknya terumbu karang disebabkan oleh penyelam. Penangkapan ikan hias dengan menggunakan kalium sianida $(\mathrm{KCN})$ yang bisa menyebabkan kematian pada karang dan avertebrata lainnya.

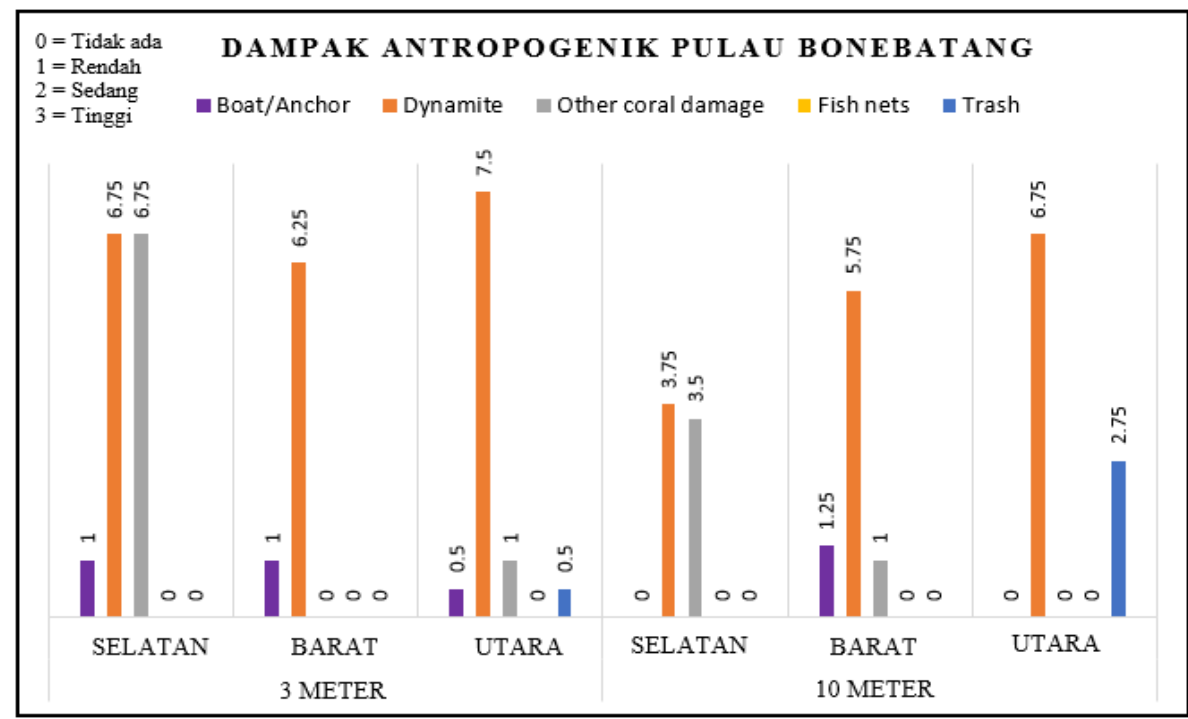

Gambar 7. Dampak antropogenik di pulau Bone Batang

Kerusakan yang disebabkan oleh faktor alami misalnya adalah kenaikan suhu, badai dan pemangsaan predator. Kenaikan suhu $4-6^{\circ} \mathrm{C}$ karena pengaruh El Nino pada tahun 1982 - 1983 disinyalir telah merusak terumbu karang di habitatnya. Di Indonesia, suhu air laut mencapai lebih dari $30^{\circ} \mathrm{C}$. Pemangsaan oleh predator misalnya oleh bintang laut pemakan karang di beberapa tempat di wilayah tropis Pasifik. Diperkirakan kerusakan akibat organisme itu dapat menghilangkan fungsi pelindung dari terumbu karang yang akhirnya mengacam stabilitas wilayah pantai (Dahuri et al. 2008).

Predator yang mampu merusak koloni karang dan memodifikasi struktur terumbu karang adalah bintang laut bulu seribu Acanthaster planci. Acanthaster planci adalah bintang laut bertangan banyak berukuran besar, yang memakan jaringan karang hidup Nybakken (1992). Adapun penyebab 
terjadinya kondisi karang dapat mengalami stress karena berubahnya kondisi lingkungan secara derastis yang menyebabkan bisa menimbulkan Penyakit. Dimana penyakit karang merupakan gejala abnormal yang menyebabkan disfungsi secara fisiologis pada kesehatan karang Beeden et al, (2008), sebagai bentuk adaptasi dari penjangkitan biotik misalnya bakteri, jamur, virus dan serangan abiotik seperti perubahan suhu air laut yang meningkat, radiasi sedimentasi, ultraviolet dan polutan Santavy et al, (1999). Penyakit bisa disebabkan karena adanya infeksi oleh patogen dan juga penyakit dapat disebabkan oleh faktor abiotik atau biotik serta kombinasinya, begitu pula dengan respon terhadap penyebab stres biologis. Untuk faktor biotik disebabkan oleh patogen seperti bakteri, protista, fungi dan virus. Sedangkan secara abiotik disebabkan oleh 2 faktor, baik itu secara alamiah atau yang disebakan oleh manusia/antropogenik. Penyakit yang disebabkan oleh faktor abiotik dan biotik seringkali berkaitan satu sama lain (Harvell et al, 2004).

Dalam penelitian Rahmi (2013), di pulau Baranglompo menemukan beberapa penyakit karang yang menginfeksi karang keras (Scleractinia) diantaranya penyakit White Syndrome (WS), Black Band Disease (BBD) dan Brown Band Disease (BrBD). Ada juga beberapa penyakit yang ditemukan di Indo pasifik seperti di Great Barrier Reef yang telah diamati oleh Willis et al,, (2004) yaitu white syndrome, skeletal eroding band, black band disease (BBD), brown band disease, growth anomalie, pink spot, dan black necrosing syndrome, sedangkan pada Karibia dan Florida Selatan, kematian karang akibat penyakit karang umumnya akibat black band disease Santavy (2005). Selanjutnya di Indonesia, penyakit black band disease (BBD) ini ditemukan di Taman Nasional Laut Wakatobi, Sulawesi Tenggara Haapkyla et al,, (2007) dan Massinai (2012) menemukan di Kepulauan Spermonde yaitu Pulau Baranglompo dan Pulau Suranti. Dari data tersebut tidak menemukan data penyakit di Bone Batang karena masih kurangnya penelitian mengenai penyakit karang di pulau tersebut. Namun, tidak menutup kemungkinan beberapa penyakit terdapat di pulau Bone Batang karena dari data di atas untuk kondisi kesehatan karang yang mengalami stress atau tidak sehat tergolong tinggi dan untuk pengambilan data juga masih dalam daerah atau zona yang sama khususnya di kepulauan spermonde.

\section{Nilai warna karang dan koloni karang}

Dari hasil pengamatan nilai warna karang untuk koloni karang bercabang, masif, meja dan lunak pada masing-masing stasiun di pulau Baranglompo dan Bone Batang diperoleh nilai warna yang bervariasi seperti pada (Gambar 8). Untuk kedalaman $3 \mathrm{~m}$, di pulau Baranglompo secara umum nilai warna karang tinggi ditemukan pada koloni karang bercabang di semua stasiun. Kondisi serupa juga ditemukan pada seluruh stasiun di Bone Batang yang didominasi oleh koloni karang bercabang. Khususnya pada stasiun barat di kedua pulau, Ini dikarenakan daerah terumbu karangnya memiliki rataan terumbu yang luas dengan kondisi topografi yang lebih landai. Kondisi seperti ini umumnya memiliki arus lebih sedang sehingga memungkinkan untuk pertumbuhan koloni karang bercabang dengan baik.

Namun di stasiun utara pulau Baranglompo ditemukan koloni karang bercabang dan koloni karang masif yang tergolong kurang sehat. Begitu juga pada stasiun barat Bone Batang untuk koloni karang kurang sehat ditemukan pada koloni karang lunak. Kondisi demikian sebagian besar dikarnakan dari dampak aktivitas manusia seperti ditemukannya bekas penggunaan bom untuk menangkap ikan yang tidak ramah lingkungan, banyaknya sampah masyarakat dan pembuangan jangkar perahu di daerah terumbu karang. Sedangkan untuk koloni karang lainnya sifatnya masih normal. 


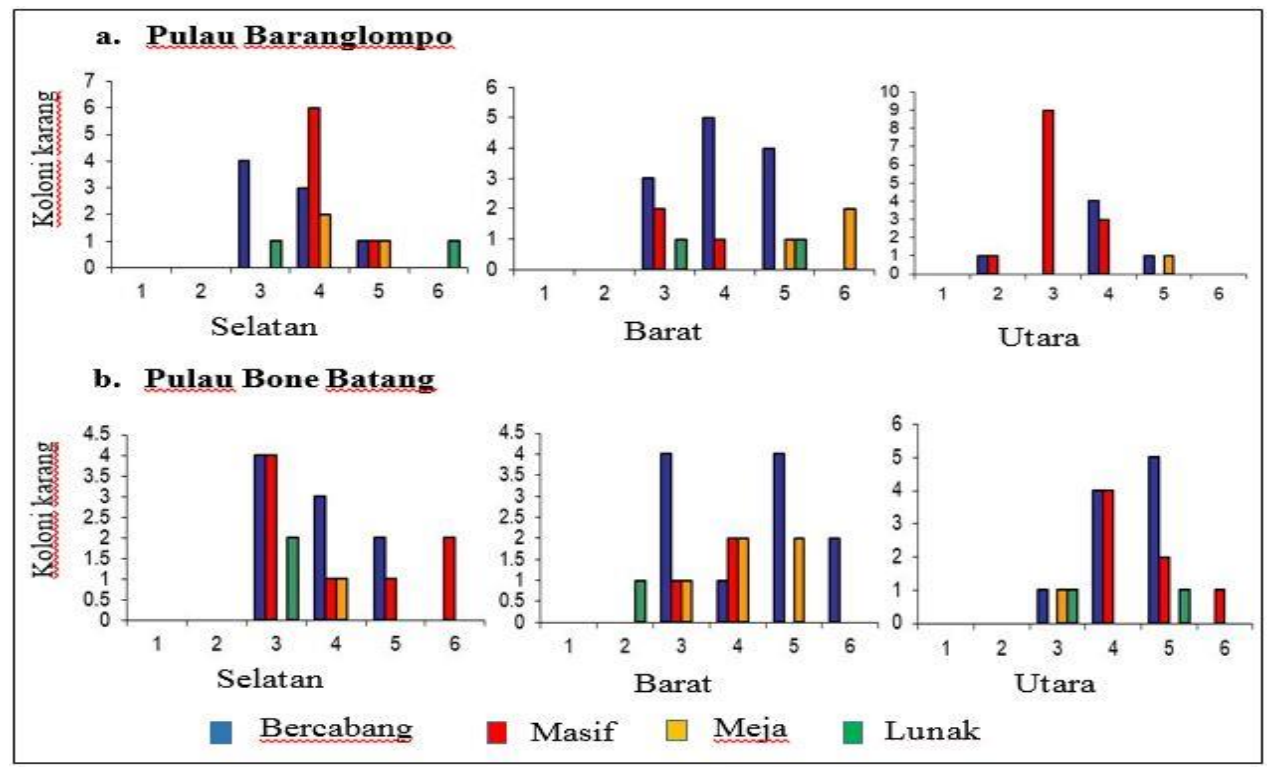

Gambar 8. Nilai warna karang $(1,2,3,4,5$, dan 6) dan koloni karang di pulau Baranglompo dan Bone Batang kedalaman $3 \mathrm{~m}$.

Menurut Sukmara (2001), ekosistem terumbu karang secara terus menerus mendapat tekanan akibat berbagai aktivitas manusia, baik secara langsung maupun tidak langsung. Beberapa aktivitas manusia yang secara langsung dapat menyebabkan kerusakan terumbu karang diantaranya adalah menangkap ikan dengan menggunakan bom dan racun sianida (potas), pembuangan jangkar, berjalan di atas terumbu, penggunaan alat tangkap muroami, penambangan batu karang, penambangan pasir, dan sebagainya. Aktivitas manusia yang secara tidak langsung dapat menyebabkan kerusakan terumbu karang adalah sedimentasi yang disebabkan aliran lumpur dari daratan akibat penggundulan hutanhutan dan kegiatan pertanian, penggunaan pupuk dan pestisida yang berlebihan untuk kebutuhan pertanian, sampah plastik, dan lain-lain. Pada kedalaman $10 \mathrm{~m}$ (Gambar 9), secara umum pada masing-masing stasiun di kedua pulau untuk nilai warna karang yang tinggi ditemukan pada koloni karang masif. Khususnya pada stasiun barat dan utara di kedua pulau. Ini dikarnkan topografi terumbu karangnya yang lebih curam dengan kondisi arus yang lebih kencang, sehingga untuk koloni karang yang dapat bertahan hidup lebih banyak atau tumbuh dengan baik yaitu koloni karang masif.

Untuk koloni karang tidak sehat ditemukan pada koloni karang meja di pulau Bone Batang pada stasiun barat dan utara. Seperti halnya pada kedalaman $3 \mathrm{~m}$ secara umum kerusakan terumbu karang karena adanya dampak dari aktivitas manusia. Sedangkan untuk koloni karang lainnya kondisi karangnya masih tergolong normal dan merata pada setiap stasiun.

Menurut Vatria (2010) Pada umumnya, kerusakan terumbu karang disebabkan oleh kegiatankegiatan perikanan yang bersifat destruktif, yaitu penggunaan bahan-bahan peledak, bahan beracun (cyanida), dan juga aktivitas penambangan karang untuk bahan bangunan, reklamasi pantai, kegiatan pariwisata yang kurang bertanggung jawab, dan sedimentasi akibat meningkatnya erosi dan lahan atas. 
Dahuri et. al. (1996) kerusakan terumbu karang dari dampak aktivitas pariwisata yaitu konstruksi (fasilitas wisata) menyebabkan dampak mekanik, merubah aliran air sekitar terumbu karang dan akhirnya merubah faktor ekologi utama terumbu karang, dapat membayangi terumbu secara lokal dengan mengurangi fotosintesis, dan dapat menjadi sumber pencemaran tetap. Buang jangkar dapat memecah dan merusak karang. Kerusakan oleh penyelam yang secara tidak sengaja menimbulkan kerusakan pada terumbu karang dan biota lainnya. Kerusakan oleh perahu kecil dimana dasar perahu dapat menabrak terumbu dan menimbulkan kerusakan fisik pada darah yang dangkal, terutama saat surut. Berjalan pada daerah terumbu dapat menyebabkan terumbu karang patah.

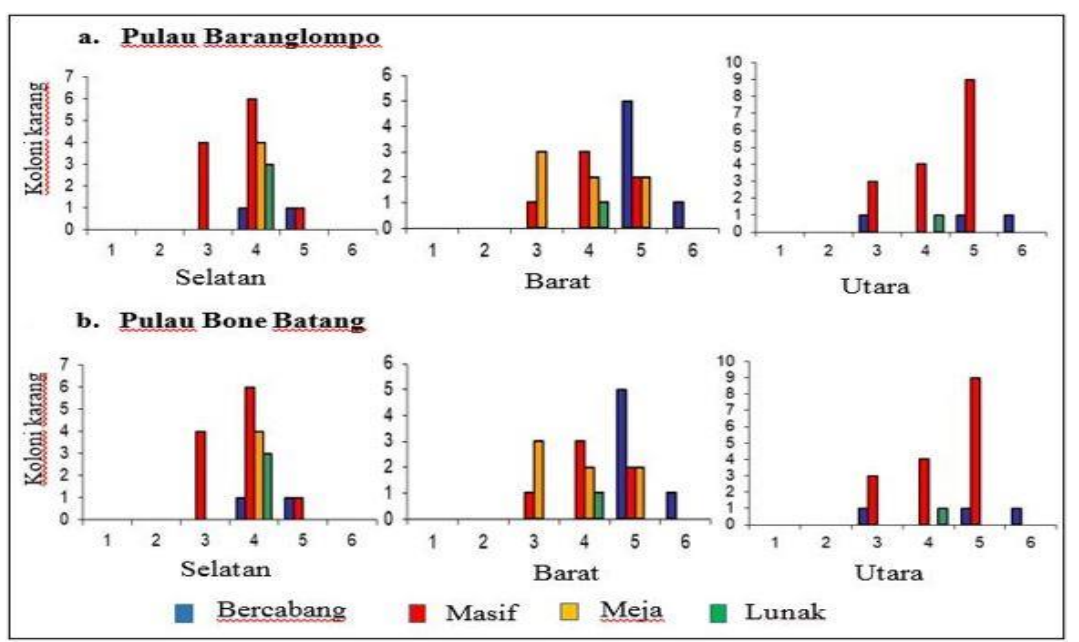

Gambar 9. Nilai warna karang (1, 2, 3, 4, 5, dan 6) dan koloni karang di pulau Baranglompo dan Bone Batamg kedalaman $10 \mathrm{~m}$

\section{Nilai warna karang dan frekuensi $(\%)$}

Hasil pengamatan untuk nilai warna karang dengan frekuensi kesehatan karang secara umum pada masing-masing stasiun di pulau Baranglompo dan Bone Batang masih tergolong sehat dan bervariasi (Gambar 10). Untuk kedalaman $3 \mathrm{~m}$ di pulau Baranglompo persentase kondisi kesehatan karangnya masih tergolong sehat di stasiun selatan dan barat pulau sedangkan stasiun utara ditemukan pemutihan karang mencapai 10\%. Bone Batang karang yang masih sehat ditemukan pada staiun selatan dan utara sedangkan di stasiun barat pulau kondisi karangnya yang tidak sehat 5\%. Dimana dari data di atas kondisi kesehatan karang tidak sehat atau stress yang menyebabkan terjadinya pemutihan pada karang. Hal ini sebagian besar diakibatkan oleh dampak dari kegiatan manusia.

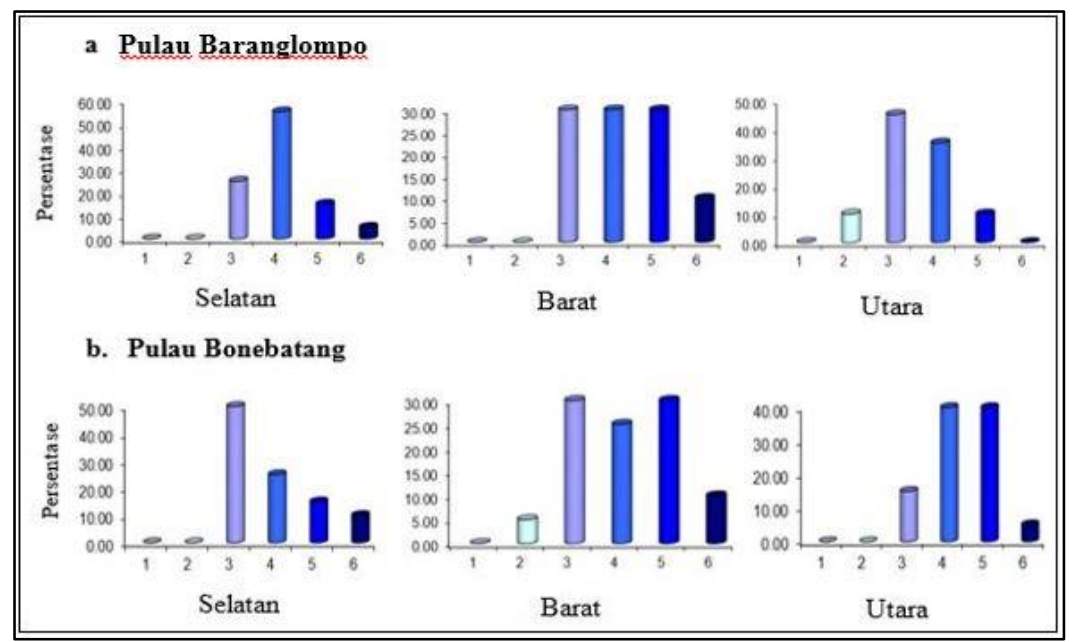

P ISSN: 2086 - 4604 
Gambar 10. Nilai warna karang $(1,2,3,4,5$, dan 6 dan frekuensi (\%)) kesehatan karang di pulau Baranglompo dan Bone Batang kedalaman $3 \mathrm{~m}$

Menurut Rani (2001), Pemanfaatan dan pembangunan kawasan pesisir, praktik penangkapan ikan yang merusak, polusi laut, dan aliran air dari penggundulan hutan dan pertanian oleh manusia merupakan ancaman terbesar bagi terumbu karang. Hayes \& Goreau (1992) dalam Rani (2001), Fenomena alam lain yang berdampak besar terhadap kondisi dan kerusakan terumbu karang ialah peristiwa pemutihan karang (coral bleaching). Pemutihan merupakan akibat dari cekaman (stress) sewaktu terjadi perubahan besar pada organisasi jaringan dan sitokimia dalam polip karang. Pada kedalaman $10 \mathrm{~m}$ (Gambar 11), kondisi kesehatan karang di pulau Baranglompo untuk semua stasiun masih tergolong sehat begitu juga pada stasiun selatan pulau Bone Batang masih tergolong sehat. Namun pada stasiun barat dan utara pulau Bone Batang kondisi karangnya tidak sehat.

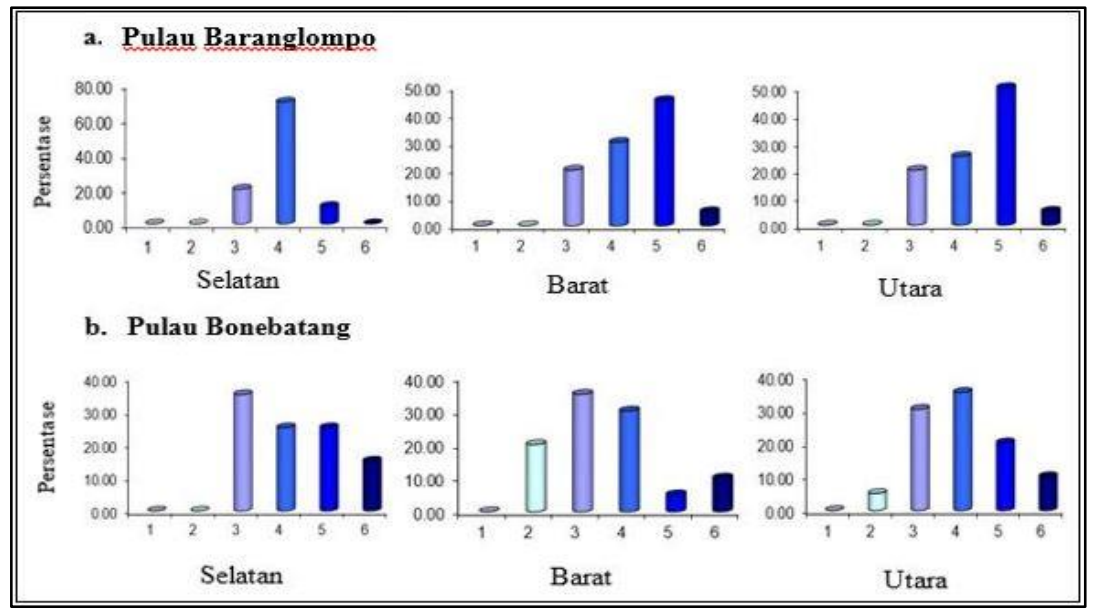

Gambar 11. Nilai warna karang $(1,2,3,4,5$, dan 6 dan frekuensi (\%) kesehatan karang di pulau Baranglompo dan Bone Batang kedalaman $10 \mathrm{~m}$

Hal ini diakibatkan juga dari dampak aktivitas manusia seperti halnya di kedalaman $3 \mathrm{~m}$. Menurut Suharsono (1996), kerusakan karang oleh sebab-sebab mekanis, misalnya adanya arus yang kuat sedimentasi, aktivitas vulkanik, perubahan tempratur dan salinitas serta penetrasi sinar matahari. Dan kerusakan karang karena aktivitas manusia seperti pencamaran minyak, bahan kimia, pengambilan karang untuk keperluan industry, bangunan, pemboman, koleksi biota laut dan lainlainnya.

\section{Kondisi kesehatan karang pulau Baranglompo dan Bone Batang}

Hasil yang ditemukan untuk kondisi kesehatan karang di pulau Baranglompo dan Bone Batang secara umum masih tergolong sehat. Namun berdasarkan hasil pengamatan pada data tabel kesehatan karang Coralwatch yang digunakan menunjukkan beberapa stasiun kondisi kesehatan karangnya masih kurang sehat. Untuk pengamatan kondisi kesehatan karang di perairan pulau Baranglompo dan Bone Batang tidak lepas dari aktivitas manusia seperti kegiatan membuang limbah rumah tangga ke dalam laut secara langsung, nelayan yang melakukan penangkapan ikan yang tidak ramah lingkungan seperti melakukan penangkapan ikan dengan bahan peledak dan bius, tumpahan minyak kapal, wisata bahari yang merusak juga mengancam kondisi terumbu karang, kegiatan kulian lapangan yang merusak, pemanasan global yang menyebabkan meningkatnya suhu di atas ambang 
batas sehingga menyebabkan terjadinya pemutihan karang (Coral Bleaching) dan terhususnya di Bone Batang beberapa masyarakat sengaja mengambil pasir sebagai bahan bangunan sehingga terjadi erosi pada pulau, secara tidak langsung akan mengganggu kondisi lingkungan karang yang menyebabkan karang mengalami stress.

Menurut Arifin dan Kepel (2013), dalam kondisi terumbu karang yang stabil, nilai tutupan komponen terumbu karang pada kedalaman $3 \mathrm{~m}$ sebesar 56\%, artinya, terumbu karang dalam kondisi bagus. Demikian halnya pada kedalaman $10 \mathrm{~m}$, tutupan juga lebih dari 50\% menunjukkan kondisi terumbu karang masih bagus. Berdasarkan tabel kontrol kesehatan karang Coralwatch untuk kondisi kesehatan karang di kedua pulau masih tergolong sehat. Dapat dilihat dari data histogram untuk frekuensi pemutihan karang (bleaching) yang ditemukan. Kesehatan karang di pulau Baranglompo dan Bone Batang juga masih sesuai dengan kontrol kesehatan karang di pulau Heron.

Menurut Nurdianti (2000), kondisi karang di pulau Baranglompo menunjukkan bahwa kondisi karangnya secara keseluruhan masi tergolong bagus dimana pada kedalaman $3 \mathrm{~m}$ persentasenya mencapai 55.69\% - 58.73\%, kondisi ini masih termasuk pada kategori bagus. Sedangkan di kedalaman $10 \mathrm{~m}$ berkisar antara $27.41 \%-37.34 \%$ dimana kategori ini termasuk sedang. Sedangkan untuk kondisi kesehatan karang pulau Bone Batang juga masih tergolong bagus hal ini sesuai denagan standar kesehatan karang Coralwatch, dimana menurut Rani et al, (2004), untuk kondisi karang di pulau Bone Batang memiliki persentase kategori karang hidup mencapai 51.94\% dan untuk kategori karang mati hanya $14.48 \%$ ini mengartikan kondisi penutupan karang masih tergolong bagus dan secara umum karangnya masih tergolong sehat. Hal tersebut ditunjukkan juga dari data kondisi lingkungan pulau Baranglompo dan Bone Batang yang disurvei seperti kondisi suhu, salinitas, $\mathrm{pH}$ dan tingkat kecerahan, dimana data tersebut sangat mendukung kelangsungan kehidupan biota laut khususnya untuk terumbu karang.

a. Suhu

Selama pengamatan di pulau Baranglompo dan Bone Batang suhu yang diperoleh yaitu $30^{\circ} \mathrm{C}$ $31^{\circ} \mathrm{C}$ dimana kondisi suhu pada daerah pengamatan masih menunjukkan dalam ambang batas untuk pertumbuhan karang. Suhu sangat berperan penting dalam kelangsungan kehidupan bawa laut khususnya karang. Dengan kondisi suhu perairan yang masih normal karang akan tumbuh dengan baik. Efek dari perubahan suhu pada karang juga dapat menyebabkan turunnya respon makan, mengurangi rata-rata reproduksi, banyak mengeluarkan lendir dan proses fotosintesis atau respirasi berkurang (Haris, 2001).

b. Salinitas air laut

Hasil pengamatn salinitas menunjukkan nilai 30\%o di pulau Baranglompo dan Bone Batang dimana data tersebut masih dalam ambang batas pertumbuhan karang dengan baik. Kondisi salinitas sangat berperan penting terhadap kelangsungan hidup karang. Kondisi dimana terjadinya perubahan salinitas diluar kondisi normal untuk pertumbuhan karang pada salinitas air laut dapat menyebabkan kematian karang. Pengambilan data kesehatan karang dilakukan pada kondisi curah hujan masih tinggi. Menurut Nontji (2005), sebaran salinitas di laut dipengaruhi oleh berbagai faktor seperti pola sirkulasi air, penguapan, curah hujan, aliran sungai. Perairan estuaria atau daerah sekitar kuala mempunyai struktur salinitas yang kompleks, pada perairan bersalinitas rendah seperti di muara sungai jarang ditemukan terumbu karang dan pada daerah bercurah hujan tinggi akan menyebabkan terumbu 
karang mengalami gangguan, begitu juga pada perairan yang kadar garamnya sangat tinggi (Nybakken, 1992).

c. $\mathrm{pH}$

Selama melakukan pengamatan, skala tingkat keasaman $\mathrm{pH}$ yang ditemukan pada pulau Baranglompo dan Bone Batang yaitu 8,1-8,3, dimana nilai ini masih sesuai dengan standar baku mutu air laut untuk biota laut. Nilai $\mathrm{pH}$ yang ideal bagi kehidupan organisme air pada umumnya terdapat antara 7 sampai 8,5. Kondisi perairan yang bersifat sangat asam maupun sangat basa, akan menyebabkan terjadinya gangguan metabolisme dan respirasi (Odum, 1994).

d. Kecerahan

Kecerahan suatu perairan sangat mempengaruhi kelangsungan hidup terumbu karang. Hail pengamatan di pulau Baranglompo dan Bone Batang menunjukkan bahwa kecerahan 12,5 m -18,5 m nilai ini masih sesuai standar baku mutu air laut untuk biota laut. Kecerahan erat kaitannya dengan intensitas cahaya matahari yang masuk ke dalam perairan. Kurangnya intensitas cahaya masuk dalam perairan akan mengganggu proses fotosintesis zooxanthellae, hal ini dapat mengurangi asupan energi untuk karang dan kurangnya asupan energi dari zooxanthellae dapat mengakibatkan karang rentan dengan penyakit (Raymundo et al, 2008).

\section{KESIMPULAN}

Kondisi kesehatan karang secara umum di pulau Baranglompo lebih baik dibandingkan pulau Bone Batang. Kondisi karang paling sehat yaitu koloni karang bercabang pada kedalaman $3 \mathrm{~m}$ dan koloni karang masif pada kedalaman $10 \mathrm{~m}$. Dampak antropogenik paling dominan di pulau Baranglompo yaitu sampah sedangkan di pulau Bone Batang yaitu bom ikan.

\section{DAFTAR PUSTAKA}

Anken, R.H. 1996. On The Taxonomic Value Of The Morphology Of Wing Scales In Some Heliconiinae (Lepidoptera,Nymphalidae). Iheringia Serie Zoologia 81: 139-144.

Beldade, P. and Brakefield, P.M. 2002. The Genetics and Evo-Devo of Butterfly Wing Patterns. Nature Reviews 3: 442-452.

Ghiradella, H. 1991. Light and Color on the Wing: Structural Colors in Butterflies and Moths. Applied Optics 30: 3492-3500.

Janssen, J.M., Monteiro, A., and Brakefield, P.M. 2001. Correlation Between Scale Structure and Pigmentation in Butterfly Wings. Evolution and Development 3: 415-423.

Kusaba, K. and Otaki, J.M. 2009. Positional Dependence of Scale Size and Shape in Butterfly Wings: Wing-Wide Phenotypic Coordination of Color-Pattern Elements and Background. Journal of Insect Physiology 55: 175-183.

Morehouse, N.I., Vukusic, P., and Rutowski, R. 2007. Pterin Pigment Granules are Responsible For Both Broadband Light Scattering and Wavelength Selective Absorption in the Wing Scales of Pierid Butterflies. Proceedings of the Royal Society London B 274 : 359-366.

Nijhout, H.F. 2001. Element of Butterfly Wing Patterns. Journal of Experimental Biology 291 : 213225. 
Peggie, D. 2011. Precious and Protected Indonesian Butterflies. Jakarta (ID): PT Binamitra Megawarna.

Prum, R.O., Quinn, T., and Torres, R.H. 2006. Anatomically Diverse Butterfly Scales All Produce Structural Colours by Coherent Scattering. Journal of Experimental Biology 209: 748-765.

Stavenga, D.G., Stowe, S., Siebke, K., Zeil, J., and Arikawa, K. 2004. Butterfly Wing Colours: Scale Beads Make White Pierid Wings Brighter. Proceedings of the Royal Society London B 271: 1577-1584.

Stavenga, D.G., Matsushita, A., Arikawa, K., Leertouwer, H.L., and Wilts, B.D. 2012. Glass Scales on the Wing of the Swordtail Butterfly Graphium sarpedon Act as Thin Film Polarizing Reflector. Journal of Experimental Biology 215: 657-662.

Tabata, H., Kumazawa, K., Funakawa, M., Takimoto, J., and Akimoto, M. 1996. Microstructures and Optical Properties of Scales of Butterfly Wings. Optical Review 3: 139-145.

Vértesy, Z., Bálint, Zs., Kertész, K., Vigneron, J.P., Lousse, V., and Biro, L.P. 2006. Wing Scale Microstructures and Nanostructures in Butterflies. Journal of Microscopy 224: 108-110.

Vukusic, P. and Sambles, J.R. 2003. Photonic Structures in Biology. Nature 424: 852-855.

Vukusic, P., Sambles, J.R., and Ghiradella, H. 2000. Optical Classification of Microstructure in Butterfly Wing-Scales. Photonics Science News 6: 61-66.

Wootton, R.J. 1992. Functional Morphology of Insect Wings. Annual Review Entomology 37: 113140.

Zhiwu, H., Liyan, W., Zhaomei, Q., and Luquan, R. 2009. Microstructure and Structural Color in Wing Scales of Butterfly Thaumantis diores. Chinese Science Bulletin 54: 535-540. 